\title{
Detection of Chlamydia trachomatis in rapidly produced McCoy cell monolayers
}

\author{
RT EVANS AND D TAYLOR-ROBINSON \\ From the Division of Communicable Diseases, MRC Clinical Research Centre, Watford Road, Harrow, \\ Middlesex HAl 3UJ, UK
}

SUMMARY The 24-hour delay between seeding coverslips with cells and inoculating samples for culture of chlamydiae was reduced to less than 1 hour by using coverslips which had been pre-treated with glutaraldehyde-activated $\gamma$-aminopropyl-triethoxysilane. Treated coverslips were not toxic for $\mathrm{McCoy}$ cells and even one year after treatment monolayers formed rapidly on them. Furthermore, all of 13 Chlamydia trachomatis serotypes and one $C$. psittaci strain tested produced inclusions in such cell monolayers. In comparative tests, when there were large numbers of inclusions, more were always seen in conventionally produced monolayers than in monolayers on treated coverslips. However, when there were few inclusions, more were seen in the latter monolayers, a phenomenon observed with unpassaged chlamydiae in clinical specimens as well as in laboratory-passaged strains. The rapid method is, therefore, as sensitive for isolating chlamydiae as using conventionally produced monolayers.

Since the introduction of cell cultures for the isolation and growth of Chlamydia trachomatis, there have been several modifications of the isolation technique which have increased the sensitivity of cells to chlamydiae and/or reduced the time needed to obtain the result of attempted isolation. ${ }^{1}$ All such techniques, however, require confluent monolayers of cells on to which the chlamydiae can be centrifuged and, therefore, there is usually a delay of 24 hours between seeding glass coverslips with a cell suspension to produce monolayers and inoculating them with chlamydiae. However, we have found that treating coverslips with the protein-linking reagent glutaraldehyde-activated $\gamma$-aminopropyl-triethoxysilane, ${ }^{2}$ a process known as derivatisation, allows confluent monolayers of cells to be produced about 30 minutes after seeding. These monolayers may be inoculated with chlamydiae immediately thereafter, and we have compared their sensitivity with monolayers of cells produced conventionally.

\section{Material and methods}

MCCOY CELLS

These were originally obtained from Dr JH Pearce (University of Birmingham) and were stored in

Received for publication 14 November 1979 liquid nitrogen. The cells were used during the course of 30 passages, after which they were discarded. The viability of cells on monolayers in these experiments was tested occasionally by the trypan-blue dye exclusion method. ${ }^{3}$ Complete medium with antibiotics (CMA) for cell maintenance and the same medium with additional nutrients for cells during chlamydial growth have been described previously. ${ }^{4}$

CHLAMY DIAE

Several serotypes of $C$. trachomatis and the EAE strain of $C$. psittaci were supplied by Dr BJ Thomas (Clinical Research Centre). Strain $78 \alpha$ of $C$. trachomatis was obtained originally from a patient who had non-gonococcal urethritis, and was used at third cell passage. Specimens containing unpassaged chlamydiae were obtained from the genital tract of male and female patients attending venereal disease clinics.

DERIVATISATION OF COVERSLIPS

Glass coverslips, $13 \mathrm{~mm}$ in diameter, were washed in Labrite (British Hydrological Corp) and then thoroughly rinsed in deionised water and air-dried. They were then gently boiled, under reflux, for 1 hour in a solution of $\gamma$-aminopropyl-triethoxysilane (Aldrich Chemical Co) in toluene $(10 \% \mathrm{v} / \mathrm{v})$. The coverslips were allowed to cool, rinsed with fresh toluene, and air-dried. They were then steeped in a 
$1 \%$ aqueous glutaraldehyde solution for 1 hour at room temperature. After rinsing in water, the coverslips were air-dried and then hot-air sterilised. Sterile coverslips were either stored at room temperature until required or each placed in a $5 \mathrm{ml}$ blood collection plastic tube (Stayne Labs, type E5/R). Untreated coverslips, after being washed in Labrite and rinsed in deionised water, were hot-air sterilised, and then added to the plastic tubes.

PREPARATION OF CELL MONOLAYERS

McCoy cell monolayers in plastic tissue-culture flasks (Nunc) were detached using versene-trypsin, and resuspended in CMA to provide a final concentration of $1 \times 10^{5}$ cells $/ \mathrm{ml}$. Two millilitres of cell suspension $\left(2 \times 10^{5}\right.$ cells $)$ in medium at room temperature were added to each tube containing an untreated coverslip. These tubes were then incubated at $37^{\circ} \mathrm{C}$ for 24 hours. Three millilitres of cell suspension $\left(3 \times 10^{5}\right.$ cells $)$ in cold meedium $\left(4^{\circ}-10^{\circ} \mathrm{C}\right)$ were added to each tube containing a derivatised coverslip, and the tubes were centrifuged at $500 \mathrm{~g}$ for 10 minutes. They were then placed in a $37^{\circ} \mathrm{C}$ water bath for 20 minutes, after which the coverslips were examined for cell confluence.

DETECTION OF CHLAMYDIAL INCLUSIONS Cell monolayer cultures were inoculated with known chlamydial serotypes or clinical specimens, centrifuged at $2800 \mathrm{~g}$ for 1 hour, and then treated with cycloheximide, as described previously. ${ }^{1}$ The cell monolayers were incubated at $37^{\circ} \mathrm{C}$ for 24 hours, and inclusions were sought by dark-ground microscopy after Giemsa staining. ${ }^{4}$

\section{Results}

APPEARANCE AND VIABILITY OF CELLS Confluent cell monolayers on each type of coverslip were indistinguishable, both having a pavement-like appearance. Examination of cell monolayers by the trypan-blue dye exclusion method showed that there were as many viable cells in monolayers on derivatised coverslips as in monolayers formed on untreated coverslips.

TESTS WITH LABORATORY-PASSAGED

CHLAMYDIAE

Thirteen $C$. trachomatis serotypes $\mathbf{A}$ to $\mathbf{I}, \mathbf{K}$, and L1, L2, and L3, and $C$. psittaci strain EAE were inoculated on to cell monolayers which had formed on both treated and untreated coverslips. All these chlamydiae grew and produced inclusions which were easily detectable in both types of cell monolayer. In all cases, however, there were more inclusions, up to twofold, detectable in cells on untreated cover-
Table 1 Number of chlamydial inclusions* in cycloheximide-treated McCoy cells on untreated or derivatised coverslips

\begin{tabular}{llcr}
\hline $\begin{array}{l}\text { Chlamydiae } \\
\text { tested }\end{array}$ & Designation & $\begin{array}{c}\text { Untreated } \\
\text { coverslips }\end{array}$ & $\begin{array}{l}\text { Derivatised } \\
\text { coverslips }\end{array}$ \\
\hline $\begin{array}{l}\text { C. trachomatis } \\
\text { serotype }\end{array}$ & & \\
A & SA1 & 517 & 312 \\
B & TW5 & 1016 & 764 \\
C & UW1 & 813 & 501 \\
D & Cal 8 & 951 & 685 \\
E & DK-20 & 785 & 701 \\
F & MRC-301 & 107 & 83 \\
G & IOL 238 & 648 & 513 \\
H & UW4 & 489 & 209 \\
I & UW12 & 560 & 495 \\
K & UW31 & 6810 & 5653 \\
L1 & 810B & 1012 & 831 \\
L2 & 434B & 925 & 628 \\
L3 & 404L & 873 & 605 \\
C.psittoci & & 427 & 351 \\
strain EAE & & & \\
\hline
\end{tabular}

* Mean number counted on two coverslips.

Table 2 Number of inclusions produced by $\mathrm{C}$. trachomatis strain 78 a in McCoy cells on untreated or derivatised coverslips

\begin{tabular}{llrr}
\hline Expt $\begin{array}{l}\text { Dilution of } \\
\text { no. }\end{array}$ & \multicolumn{2}{c}{ No. of inclusions $*$ in cell monolayers ${ }^{\text {chlam }}$ formed on } \\
\cline { 3 - 4 } suspension & Untreated coverslips & Derivatised coverslips \\
\hline 1 & $1 / 40$ & 30287 & 10637 \\
& $1 / 400$ & 1251 & 1192 \\
& $1 / 8000$ & 17 & 49 \\
2 & $1 / 80$ & 11354 & 6983 \\
& $1 / 800$ & 1086 & 705 \\
& $1 / 8000$ & 123 & 67 \\
& $1 / 16000$ & 8 & 12 \\
3 & $1 / 80$ & 15767 & 6930 \\
& $1 / 800$ & 1730 & 581 \\
& $1 / 8000$ & 128 & 65 \\
& $1 / 80000$ & 1 & 2 \\
\hline
\end{tabular}

* Mean number counted on two coverslips.

†Treated with cycloheximide.

slips than in those on derivatised coverslips (Table 1).

Various dilutions of a suspension of $C$. trachomatis strain $78 \alpha$ were also tested, using monolayers of cells formed on both types of coverslip (Table 2). When large numbers of inclusions developed (more than 50 per coverslip), more were seen in monolayers of cells formed on untreated coverslips than in those on derivatised coverslips. However, when the numbers of inclusions were small, the reverse was seen. There were no instances of inclusions being detected in one type of cell monolayer but not in the other.

TESTS WITH CLINICAL SPECIMENS

Isolation of chlamydiae from clinical specimens was carried out by dividing each specimen equally 
between the two types of cell monolayer. Chlamydiae were isolated from 20 of 47 patients using cell monolayers on untreated coverslips and from 19 patients using cell monolayers on derivatised coverslips. As before, when the numbers of inclusions were large (more than 50 per coverslip), more were detected in cell monolayers on untreated coverslips, but when the numbers were small, more were seen in cell monolayers formed on derivatised coverslips. The only exception was the specimen from which chlamydiae were not isolated using cell monolayers on derivatised coverslips; in this case, two inclusions were detected in cells on an untreated coverslip.

STORAGE OF COVERSLIPS

After storage at room temperature for up to 15 months, sterile derivatised coverslips had not lost the property of allowing cells to form monolayers rapidly on them. Furthermore, the numbers of chlamydial inclusions formed in such cell monolayers were no different from those formed in cell monolayers on freshly prepared derivatised coverslips.

\section{Discussion}

Previously ${ }^{1}$ we compared the various ways of treating McCoy cells that had been advocated for increasing their sensitivity to $C$. trachomatis and showed that the greatest increase in the number of inclusions was obtained by treatment with cycloheximide. This increase in inclusion number has been observed not only with our own McCoy cells but also with McCoy cells obtained from other laboratories. For this reason it was reasonable to compare only cycloheximide-treated McCoy cell monolayers on derivatised coverslips with similar cells on untreated coverslips. The procedure we have described binds the protein of the cells to the glass, the protein-aminoalkylsilane-glass complex being referred to as a derivative and hence the term derivatisation. The procedure allows the formation of stable monolayers of cells within 30 minutes whereas cells centrifuged on to untreated glass do not form stable monolayers for many hours (Evans, unpublished observation).

When there were large numbers of inclusions, the number found in cells on derivatised coverslips was smaller than the number in cells on untreated coverslips. This might indicate a lack of sensitivity on the part of the new method. However, when a few inclusions only were found, more were detected in cells on derivatised coverslips than on untreated coverslips. This suggests that the derivatised coverslip method is as sensitive as other methods for the isolation of chlamydiae, although we have no satisfactory explanation for the apparent, albeit constant, dual sensitivity of the cells.

The advantage of the derivatised coverslip method over existing methods is that confluent monolayers of cells may be produced rapidly. Recently, $C$. trachomatis has been implicated in neonatal pneumonitis $^{5}$ and aortic valve disease ${ }^{6}$ so that it is of interest not only to venereologists and ophthalmologists but to those in other medical specialties too. This consequently leads to a greater interest in culturing the microorganism in hospital microbiology laboratories. The need for a specialised cell line and culture technique, together with the relatively few cases of non-venereal chlamydial disease encountered, have tended to mean that specimens for chlamydial isolation are either passed to specialist laboratories, or are stored for batch testing, or isolation attempts are not made, diagnosis being based on the inefficient complement-fixation technique. However, the use of the method described here means that virology laboratories could maintain the McCoy cell line on a passage-only basis, monolayers being prepared as they are needed. Furthermore, coverslips could be treated in advance and stored aseptically until required. This method, combined with Giemsa staining of inclusions, enables results to be available within 48 hours of a sample arriving in the laboratory. If the method was combined with immunofluorescence staining of inclusions, ${ }^{4}$ results would be available within 24 hours.

We thank Dr PE Munday for collecting the clinical samples.

\section{References}

${ }^{1}$ Evans RT, Taylor-Robinson D. Comparison of various McCoy cell treatment procedures used for the detection of Chlamydia trachomatis. J Clin Microbiol 1979;10:198-201.

2 Robinson PJ, Dunnill P, Lilly MD. Porous glass as a solid support for immobilisation or affinity chromatography of enzymes. Biochim Biophys Acta 1971; 242:659-61.

${ }^{3}$ Phillips HJ. Dye exclusion test for cell viability. In: Kruse PF Jr, Patterson MK Jr, eds. Tissue Culture: Methods and Application. New York: Academic Press, 1973:406-12.

4 Thomas BJ, Evans RT, Hutchinson GR, TaylorRobinson D. Early detection of chlamydial inclusions combining the use of cycloheximide-treated McCoy cells and immunofluorescence staining. $J$ Clin Microbiol 1977;6:285-92.

${ }^{5}$ Beem MO, Saxon EM. Respiratory-tract colonization and a distinctive pneumonia syndrome in infants 
infected with Chlamydia trachomatis. $N$ Engl J Med 1977;296:306-10.

- Van der Bel-Kahn JM, Watanakunakorn C, Menefee MG, Long HD, Dicter R. Chlamydia trachomatis endocarditis. Am Heart J 1978;95:627-36.
Requests for reprints to: Dr D Taylor-Robinson, Division of Communicable Diseases, MRC Clinical Research Centre, Watford Road, Harrow, Middlesex HA1 3UJ, UK.

\section{Reports and Bulletins prepared by the Association of Clinical Biochemists}

The following reports and bulletins are published by the Association of Clinical Biochemists. They may be obtained from The Publishing Department, British Medical Journal (ACB Technical Bulletins), BMA House, Tavistock Square, London WCIH 9JR. Overseas readers should remit by British Postal or Money Order.

SCIENTIFIC REVIEWS (price $£ 1 \cdot 00 / \$ 2.00$ each)

1 The assessment of thyroid function March 1971 FV FLYNN and JR HOBBS

2 Renal function tests suitable for clinical practice January 1972 FL MITCHELL, N VEALL, and RWE WATTS

3 Biochemical tests for the assessment of fetoplacental function May 1975 CE WILDE and RE OAKEY

4 Test of exocrine pancreatic function March 1977 AH GOWENLOCK

5 Assay of cholinesterase in clinical chemistry 1979 ELSIE SILK, J KING, and MARY WHITTAKER

March

TECHNiCAL BULLETINS (price $£ 1 \cdot 00 / \$ 2.00$ each)

22 Bilirubin standards and the determination of bilirubin by manual and technicon AutoAnalyzer methods January 1971 BARBARA BILLING, RUTH HASLAM, and N WALD

23 Interchangeable cells for spectrophotometers and fluorimeters September 1971 Ss BROWN and AH GOWENLOCK

24 Simple tests to detect poisons March 1972 BW MEADE et al.

25 Blood gas analysers May 1972 K DIxON

26 Kits for enzyme activity determination September 1972 SB ROSALKI and D TARLOW

27 Assessment of pumps suitable for incorporation into existing continuous flow analytical systems November 1972 A FLECK et al.

28 Routine clinical measurements of transferrin in human serum September 1973 K DIXON
29 Control materials for clinical biochemistry (5th edition) September 1973 JF STEVENS

30 Notes on the quality of performance of serum cholesterol assays September 1973 ss BROWN

31 Determination of uric acid in blood and in urine July 1974 RWE WATTS

32 A survey of amino acid analysers readily available in the United Kingdom September 1974 JE CARLYLE and P PURKISS

33 Definitions of some words and terms used in automated analysis November 1974 A FLECK, R ROBINSON, SS BROWN, and JR HOBBS

34 Measurement of albumin in the sera of patients January 1975 LINDA SLATER, PM CARTER, and JR HOBBS

35 Investigation of the validity of temperature correction factors for serum aspartate and alanine transaminases March 1975 SB ROSALKI et al.

36 Factors influencing the assay of creatinine November 1975 JGH COOK

37 A survey of enzyme reaction rate analysers readily available in the United Kingdom July 1977 RA SAUNDERS and RF BURNS

38 Transport of specimens for clinical chemistry analysis November 1977 P WILDING, JF ZILVA, and CE WILDE

39 A scheme for the evaluation of diagnostic kits May 1978 PH LLOYD

40 A practical guide to gamma-counting in radioimmunoassay January 1980 CE WILDE and D OTTEWELL 